\title{
Neutrophil Adherence to Isolated Adult Canine Myocytes Evidence for a CD18-dependent Mechanism
}

\author{
Mark L. Entman,“ Keith Youker, ${ }^{*}$ Scott B. Shappell,” Craig Siegel,* Robert Rothlein, \\ William J. Dreyer, ${ }^{\ddagger}$ Frank C. Schmalstieg," and C. Wayne Smith ${ }^{\ddagger}$ \\ *Section of Cardiovascular Sciences, The Methodist Hospital and The DeBakey Heart Center, Department of Medicine, and ${ }^{\ddagger}$ Speros $P$. \\ Martel Laboratory of Leukocyte Biology, Department of Pediatrics, Baylor College of Medicine, Houston, Texas 77054; \\ ${ }^{\S}$ Department of Immunology/Cell Biology, Boehringer Ingelheim Pharmaceuticals Inc., Ridgefield, Connecticut 06877; and \\ "Department of Pediatrics, University of Texas Medical Branch, Galveston, Texas 77550
}

\begin{abstract}
Cardiac myocytes were isolated from adult dogs and incubated with isolated canine neutrophils (PMN). Intercellular adhesion was low and unchanged by stimulation of the PMN with zymosan activated serum or platelet activating factor (PAF) at concentrations that significantly enhance PMN adhesion to protein-coated glass and canine endothelial cell monolayers. Intercellular adhesion was significantly increased only when both myocytes and PMN were stimulated (e.g., myocytes incubated with IL-1, tumor necrosis factor, or phorbol myristate acetate, and PMN were chemotactically stimulated). Inhibitors of protein synthesis diminished the IL-1 $\beta$-induced effect by $>80 \%$. The IL-1 $\beta$, PAF-stimulated PMN-myocyte adhesion was associated with substantial $\mathrm{H}_{2} \mathrm{O}_{2}$ production. Under conditions with low PMN-myocyte adhesion (i.e., IL-1 $\beta$ alone, PAF alone, or no stimulus) $\mathrm{H}_{2} \mathrm{O}_{2}$ production was generally $<5 \%$ of that occurring with high adhesion. An anti-CD18 monoclonal antibody (R15.7) inhibited stimulated PMN-myocyte adhesion by $>95 \%$ and reduced $\mathrm{H}_{2} \mathrm{O}_{2}$ production by $>90 \%$. Control isotype-matched, binding, and nonbinding antibodies were without effect on adherence or $\mathrm{H}_{2} \mathrm{O}_{2}$ production. The results indicate that cytokine stimulation of adult myocytes induces expression of a ligand involved in CD18-dependent adherence of canine neutrophils. (J. Clin. Invest. 1990. 85:1497-1506.) cytokines - hydrogen peroxide - chemotactic factors $\bullet$ monoclonal antibodies $\bullet$ endothelium
\end{abstract}

\section{Introduction}

Neutrophils apparently contribute to the injury of myocardial tissue after occlusion of the coronary artery, particularly under conditions where the ischemic tissue is subsequently reperfused with normally oxygenated blood $(1,2)$. Neutrophil attachment to vessel walls and emigration into cardiac tissue begins shortly after the initiation of reperfusion (3-8), and various experimental manipulations in animal models designed to remove neutrophils from the circulation $(3,6,9-12)$ or to inhibit their functions (13-18) have resulted in measurable reductions in the extent of myocardial damage after isch-

Address correspondence to Dr. C. Wayne Smith, Texas Children's Hospital, Clinical Care Center, 8080 N. Stadium, Suite 2100, Houston, TX 77054.

Received for publication 21 July 1989 and in revised form $13 \mathrm{De}$ cember 1989.

J. Clin. Invest.

(C) The American Society for Clinical Investigation, Inc. 0021-9738/90/05/1497/10 \$2.00

Volume 85, May 1990, 1497-1506 emia and reperfusion. The mechanisms by which neutrophils effect this tissue damage remain uncertain, though two possibilities have been supported by experimental evidence. The first is that these leukocytes physically obstruct capillaries, thereby limiting reperfusion $(19,20)$. The second is that secretory products (e.g., oxygen radicals) from the emigrating neutrophils are responsible for cytotoxic effects on myocytes $(1,2$, 8). Changes in leukocyte adhesion contribute to both mechanisms. Adherence to capillary endothelium promotes retention of leukocytes within vessels, and is clearly necessary for emigration of neutrophils into extravascular sites (21-23). Additionally, attachment of extravascular neutrophils to tissue cells would provide a small distance over which cytotoxic molecules act, and yield a relatively high concentration of these molecules. Furthermore, it would possibly enhance neutrophil secretory responses $(24,25)$. While adhesion of neutrophils to extracellular matrix proteins (26-30) and endothelial cells (31-45), and transendothelial migration $(42,43,46-48)$ have received considerable attention, including characterization of molecular mechanisms, adhesive interactions of neutrophils with cardiac myocytes have not been evaluated.

In this study we address the hypothesis that inflammation in myocardial tissue promotes the adhesion of neutrophils to cardiac myocytes, and this adhesion augments the secretory activity of neutrophils. Experiments were performed in vitro using isolated myocytes and neutrophils, and defined inflammatory mediators such as cytokines and chemotactic factors. The results demonstrate adhesion of canine neutrophils to canine myocytes in vitro, identify several specific stimuli that activate this adhesion, and provide evidence that production of $\mathrm{H}_{2} \mathrm{O}_{2}$ is associated with this adhesion. In addition, using a $\mathrm{MAb}$ reactive with canine neutrophil $\mathrm{CD} 18$, we provide evidence that the stimulated adhesion and $\mathrm{H}_{2} \mathrm{O}_{2}$ production are CD1 8 dependent.

\section{Methods}

Isolation of cardiac myocytes. Healthy mongrel dogs weighing 10-15 $\mathrm{kg}$ were anesthetized using sodium pentobarbital. The heart was removed through the left lateral chest under sterile conditions and immediately placed in ice-cold saline. The aorta was then cannulated using a tubing adapter suitable for the individual heart. The adapter was then connected to a peristaltic pump and retrograde perfusion was initiated at $50-60 \mathrm{ml} / \mathrm{min}$ using medium A (Joklik modified minimum essential medium, containing $2 \mathrm{~g} /$ liter sodium bicarbonate, $0.1 \%$ fatty acid-free $\mathrm{BSA}$ and equilibrated with $95 \% \mathrm{O}_{2} / 5 \% \mathrm{CO}_{2}$ before perfusion; Sigma Chemical Co., St. Louis, MO). Perfusion was maintained several minutes until all left ventricle vessels were cleared of blood. The perfusate was then changed to medium B (medium A containing 120 $\mathrm{U} / \mathrm{ml}$ collagenase type III; Worthington Biochemical Corp., Freehold, $\mathrm{NJ}$ ) and perfusion continued for $10 \mathrm{~min}$. At this point the heart was removed from the cannulae and $10 \mathrm{~g}$ of left ventricle were minced and 
placed in an Erlenmeyer flask containing $50 \mathrm{ml}$ medium B. The flask was equilibrated with $95 \% \mathrm{O}_{2} / 5 \% \mathrm{CO}_{2}$ gas, sealed, and placed in a shaker bath at $90-100 \mathrm{cycles} / \mathrm{min}$ at $35^{\circ} \mathrm{C}$. After $20 \mathrm{~min}$ the supernatant was filtered through one layer of cheesecloth, another $50 \mathrm{ml}$ of medium B was added, and the procedure was repeated five to six times. These cells were allowed to settle at room temperature for $\sim 5 \mathrm{~min}$ and the overlying solution was removed. The cell pellet was then suspended in medium A and the cells were allowed to settle. This wash was then repeated and viability was measured using trypan blue dye exclusion. Preparations with a viability of $>80 \%$ were used in incubation experiments with neutrophils. Cells were then placed on ice and used within one to two days. Viability and adhesion after stimulation were not appreciably altered over this period.

Neutrophil isolation. Canine neutrophils were isolated from citrate anticoagulated venous blood using techniques previously described for the isolation of human neutrophils (43). This yielded a preparation of cells $>95 \%$ neutrophils with $>99 \%$ viability. These cells were suspended in Dulbecco's PBS and stored at $4^{\circ} \mathrm{C}$ for up to $4 \mathrm{~h}$. Blood was also obtained on two occasions from a dog with CD18 deficiency (49) (provided by Dr. U. Giger, University of Pennsylvania, Philadelphia).

$M A b s$. A monoclonal antibody (IgG1) without binding specificity for canine cells was provided as purified IgG from Damon Biotech (Needham Heights, MA) and served as a nonbinding control. The clone producing the MAb LM2/1 (IgG1) (50) was obtained from Dr. T. Springer (The Center for Blood Research, Boston, MA). A new MAb was prepared by immunizing BALB/c mice with canine peritoneal macrophages and subsequently fusing spleen cells with $\mathrm{P} 3 \mathrm{X} 63 \mathrm{Ag} 8.653$ myeloma cells according to the protocol of Galfre et al. (51). Supernatants were screened for inhibition of JY cell and SKW3 aggregation (52). Clones positive in both assays were subsequently screened for binding to mouse/human hybrid cells expressing mouse CD11a and human CD18 (53). One clone, R15.7, was selected for further characterization (see Results) as a potential anti-canine CD18 MAb. It was determined to be an IgG1 by Ouchterlony (ICN Biomedicals, Inc., Irvine, CA). Ascites fluid was prepared in pristane-primed BALB/c mice for each of the R15.7 and LM2/1 clones, and IgG was isolated on protein A.

Immunoprecipitation studies. Fresh canine granulocytes $\left(2.2 \times 10^{8}\right.$ cells) were labeled with ${ }^{125} \mathrm{I}(10 \mathrm{mCi})$ by lactoperoxidase and glucosidase as previously described (42). The cells were solubilized in $2 \mathrm{ml}$ of lysis buffer $(0.5 \% \mathrm{NP}-40,10 \mathrm{mg} /$ liter aprotinin, $1 \mathrm{mg} /$ /iter pepstatin, 1 $\mathrm{mg} /$ liter leupeptin, $1 \mathrm{mM}$ EDTA, $50 \mu \mathrm{M}$ sodium vanadate, $0.15 \mathrm{M}$ sodium chloride, and $0.15 \mathrm{~m}$ Tris, $\mathrm{pH}$ 7.6). After removal of cell debris by centrifugation, the lysates $(200 \mu \mathrm{l})$ were precleared three times with $50 \mu l$ glycine- $\mathrm{HCl}$ quenched cyanogen bromide-activated Sepharose beads, and then three times with $50 \mu \mathrm{l}$ of protein A coupled to Sepharose. The lysates $(200 \mu \mathrm{l})$ were then mixed with the following ascites fluids: $0.5 \mu \mathrm{lTS} 1 / 22,1 \mu \mathrm{l} \mathrm{OKM}-1$, and $0.2 \mu \mathrm{l} \mathrm{TS} 1 / 18$ (clones provided by Dr. T. Springer). The same volume of lysate was also mixed with 2 $\mu 1$ of a polyclonal rabbit anti-human beta subunit and with $5,10,25$, 50 , and $100 \mu \mathrm{l}$ R 15.7 ascites. After a 4-h incubation, $25 \mu \mathrm{l}$ of protein A bound to Sepharose beads was added with tipping for $2 \mathrm{~h}$. The beads were then washed and boiled in SDS sample buffer (2.5\% SDS and 5\% mercaptoethanol, wt/vol) for $2 \mathrm{~min}$. SDS-PAGE (7.5\% acrylamide) and autoradiography were performed as previously described (42).

Immunofluorescence flow cytometry. Indirect immunofluorescence assessments of the surface expression of binding sites for MAbs LM2/1 and R15.7 were performed using saturating concentrations of the MAbs and FITC-conjugated rabbit anti-mouse IgG (54). Analysis was carried out with a FACScan (Becton Dickinson Immunocytometry Systems, Mountain View, CA). The nonbinding IgG1 served as control. Results are expressed as mean fluorescence channel on a log scale.

Aggregometry and chemotaxis. Homotypic aggregation of canine neutrophils was performed using a technique developed for human neutrophils (55). Phorbol myristate acetate (PMA; Sigma Chemical Co., St. Louis, MO) was used as the stimulus for aggregation, and the neutrophils were incubated with MAb for $5 \mathrm{~min}$ at $37^{\circ} \mathrm{C}$ before addition of the PMA.
Chemotactic migration was determined using the leading front assay with micropore filters as previously described (56). One chemotactic stimulus used in these studies was zymosan-activated canine serum (ZAS). ${ }^{1}$ It was prepared by incubating $10 \mathrm{mg}$ of zymosan (Sigma Chemical Co.) in $1 \mathrm{ml}$ fresh canine serum at $37^{\circ} \mathrm{C}$ for $45 \mathrm{~min}$. The zymosan was removed by centrifugation and the ZAS was heated at $56^{\circ} \mathrm{C}$ for $30 \mathrm{~min}$. A second chemotactic substance used in these studies was platelet activating factor (PAF; $\mathrm{L}-\alpha$-phosphatidyl-choline, $\beta$-acetyl$\gamma$-O-alkyl, Sigma Chemical Co.). PAF was initially dissolved in chloroform at a concentration of $200 \mathrm{ng} / \mu \mathrm{l}$. Before use, the appropriate volume was evaporated to dryness and the PAF suspended at a concentration of $1 \mu \mathrm{g} / \mathrm{ml}$ in PBS containing $1 \%$ human serum albumin (HSA; Sigma Chemical Co.). Dilutions used in functional studies were made in PBS without additional HSA.

Canine neutrophil adherence to canine endothelial monolayers and protein-coated glass. Canine jugular vein endothelial cells were obtained by a modification of the method of Ford et al. (57). Jugular veins were everted on glass rods and incubated in collagenase solution (type III, $50 \mathrm{U} / \mathrm{ml}$; Worthington Biochemical Corp.) for $10 \mathrm{~min}$. Cells were collected by centrifugation and suspended in DME containing $4 \%$ FCS, $4 \%$ bovine calf serum, $50 \mu \mathrm{g} / \mathrm{ml}$ endothelial cell growth factor (Collaborative Research Inc., Lexington, MA), $50 \mu \mathrm{g} / \mathrm{ml}$ heparin, 1 $\mathrm{mM}$ sodium pyruvate, and antibiotics. Cells were seeded in Primaria flasks (Becton Dickinson, Lincoln Park, NJ). After 2-4 d of incubation at $37^{\circ} \mathrm{C}$ in a $\mathrm{CO}_{2}$ incubator, areas of cells with cobble-stone morphology were collected by scraping, transferred to gelatin-coated flasks, and grown to confluence. Second passage cells were obtained by scraping, seeded onto type I collagen-coated $(5 \mu \mathrm{g} / \mathrm{ml}) 25-\mathrm{mm}$ round cover glasses, and grown to confluence. Only preparations of cells where representative uniform monolayers exhibited acetylated low density lipoprotein (Dilac-LDL; Biomedical Technologies, Inc., Stoughton, MA) uptake and endothelial (cobble-stone) morphology were used in adhesion assays. Coverslips with attached endothelial monolayers were inserted in adhesion chambers, and adherence of isolated canine neutrophils was determined in the absence of shear stress using a visual assay as previously described $(42,43)$. In experiments with stimulated endothelial cells, monolayers were exposed to $2 \mathrm{ng} / \mathrm{ml} \mathrm{LPS}$ (Escherichia coli; Sigma Chemical Co.) for $3 \mathrm{~h}$ at $37^{\circ} \mathrm{C}$, rinsed by dipping the coverslip five times in two changes of PBS before being inserted into the adherence chambers. In experiments with MAbs, neutrophils were exposed to the antibodies at room temperature for $5 \mathrm{~min}$ before the cell suspension containing the antibodies was injected into the adherence chambers.

Adhesion of neutrophils to serum-treated glass was determined as previously described (56). Coverglasses were exposed to $3 \%$ canine serum in PBS for 2 min, then rinsed in PBS and inserted in the adherence chamber. Adhesion was determined using a visual assay in the absence of shear stress.

Canine neutrophil-myocyte adherence. Isolated canine myocytes were suspended in medium A at a concentration of $50,000 / \mathrm{ml}$. Neutrophils and myocytes were co-incubated in a volume of $0.4 \mathrm{ml}$ at a ratio of $10: 1$, neutrophils/myocytes, for $30 \mathrm{~min}$ at $37^{\circ} \mathrm{C}$. The cells were resuspended, a small aliquot was transferred to a microscope slide and covered with a coverglass, and cells were examined under phase contrast or differential interference contrast optics. The percentage of myocytes with $>2$ attached neutrophils was determined and the number of neutrophils per myocyte was counted on 200 myocytes per preparation. Samples were coded so that data collection was performed without knowledge of the specific experimental conditions. In experiments with stimulated myocytes, myocytes were incubated with IL- $1 \beta$ and recombinant IL-1 $\beta$ (Genzyme Corp., Boston, MA), tumor necrosis factor (TNF $\alpha$; Boehringer Ingelheim, Ridgefield, CT), or PMA

1. Abbreviations used in this paper: ELAM-1, endothelial leukocyte adhesion molecule-1; HSA, human serum albumin; ICAM-1, intercellular adhesion molecule-1; PAF, platelet activating factor; TNF, tumor necrosis factor; ZAS, zymosan-activated canine serum. 
for various times at $37^{\circ} \mathrm{C}$ before addition of the neutrophils. In experiments with stimulated neutrophils, PAF or ZAS was added immediately before the neutrophil suspension was mixed with the suspension of myocytes. MAbs were added to the neutrophil-myocyte suspension $(10 \mu \mathrm{g} / \mathrm{ml})$ at the beginning and remained with the cells throughout the incubation period.

Evaluation of the effects of protein synthesis inhibitors on the cytokine-induced myocyte-neutrophil adhesion was carried out in the following way: Myocytes were incubated for $3 \mathrm{~h}$ at $37^{\circ} \mathrm{C}$ in the presence of IL-1 $\beta(2 \mathrm{U} / \mathrm{ml})$ with and without actinomycin $D(5 \mu \mathrm{g} / \mathrm{ml})$ or cycloheximide ( $5 \mu \mathrm{g} / \mathrm{ml}$ ) (both from Sigma Chemical Co.). Adhesion was assessed as described above using ZAS-stimulated neutrophils. Protein synthesis was assessed by determining the incorporation of $\left[{ }^{3} \mathrm{H}\right]$ leucine $(10 \mu \mathrm{Ci} / \mathrm{ml}$; ICN Biomedicals, Inc., Costa Mesa, CA) added at the same time as IL- $1 \beta$, using the method of Sen et al. (58).

Evaluation of hydrogen peroxide production. $\mathrm{H}_{2} \mathrm{O}_{2}$ production was quantitated in 96-well polystyrene microtiter plates by a modification of the method described by Nathan $(24,25)$. Plates were coated with collagen type I (Collaborative Research Inc.) $(150 \mu \mathrm{l} /$ well of a 0.5 $\mathrm{mg} / \mathrm{ml}$ solution in PBS) for $30 \mathrm{~min}$ at $37^{\circ} \mathrm{C}$ and washed three times with PBS. The assay reaction mixture $(100 \mu \mathrm{l} /$ well $)$ was $24 \mu \mathrm{M}$ scopoletin (Sigma Chemical Co.), $5 \mu \mathrm{g} / \mathrm{ml}$ horseradish peroxidase (type II; Sigma Chemical Co.), $1 \mathrm{mM}$ sodium azide, and $5 \mathrm{mM}$ glucose in low phosphate Krebs-Ringer buffer. Unstimulated or stimulated myocytes $\left(4 \mathrm{U} / \mathrm{ml} \mathrm{IL}-1 \beta\right.$ for $3-4 \mathrm{~h}$ at $37^{\circ} \mathrm{C}$ ) were added to appropriate wells (2,000 cells/well). MAbs and PAF were added immediately before the addition of canine neutrophils $\left(6 \times 10^{5} /\right.$ well $)$. Experiments were performed in replicates of six to eight each, and fluorescence of scopoletin was determined immediately after addition of neutrophils and at 15min intervals thereafter in a Titertek Fluoraskan II fluorometer (Flow Laboratories, Inc., McLean, VA) with excitation and emission wavelengths of 355 and $460 \mathrm{~nm}$, respectively. Values for $\mathrm{H}_{2} \mathrm{O}_{2}$ production were plotted and the areas under the curve determined using a digitizing pad and Sigma-Scan software (Jandel Scientific, Sausalito, CA).

Data presentation. Results are presented as means $\pm 1 \mathrm{SD}$, and $n$ $=$ the number of separate experiments. Statistical assessments were made using analysis of variance and Dunnett's $t$ test or Student's $t$ test.

\section{Results}

The rod-shaped appearance of viable isolated myocytes (59) (Fig. $1 \mathrm{~A}$ ) was evident in $>80 \%$ of the cells in preparations used in these studies. Co-incubation of neutrophils and myocytes at $37^{\circ} \mathrm{C}$ for periods up to $1 \mathrm{~h}$ resulted in a low incidence of intercellular adhesion with a mean of less than one neutrophil/myocyte. Neutrophils failed to adhere to myocytes with a rounded configuration, cells that typically stained with trypan blue. Exposure of co-incubated neutrophils and myocytes to PMA resulted in a marked increase in adherence (Fig. 2), evident in $\sim 1 \mathrm{~h}$. This stimulus resulted in aggregation of neutrophils, the attachment of neutrophils to individual myocytes, and some large clumps of neutrophils containing several myocytes. Since PMA may activate both neutrophils and myocytes, an effort was made to distinguish contributions of each cell type. Stimulation of neutrophils with ZAS $(0.1-0.5 \%)$ or PAF $(5-500 \mathrm{ng} / \mathrm{ml})$ significantly increased adherence to serum-coated glass or monolayers of canine endothelial cells (Table I) (maximum adhesion was reached at $0.2-1.0 \%$ concentrations of ZAS and $30-500 \mathrm{ng} / \mathrm{ml}$ PAF), induced migration in the leading front assessment of the chemotaxis assay (migration toward serum, $35 \pm 5 \mu \mathrm{m} ; 1 \% \mathrm{ZAS}, 125 \pm 6 \mu \mathrm{m} ; 1 \%$
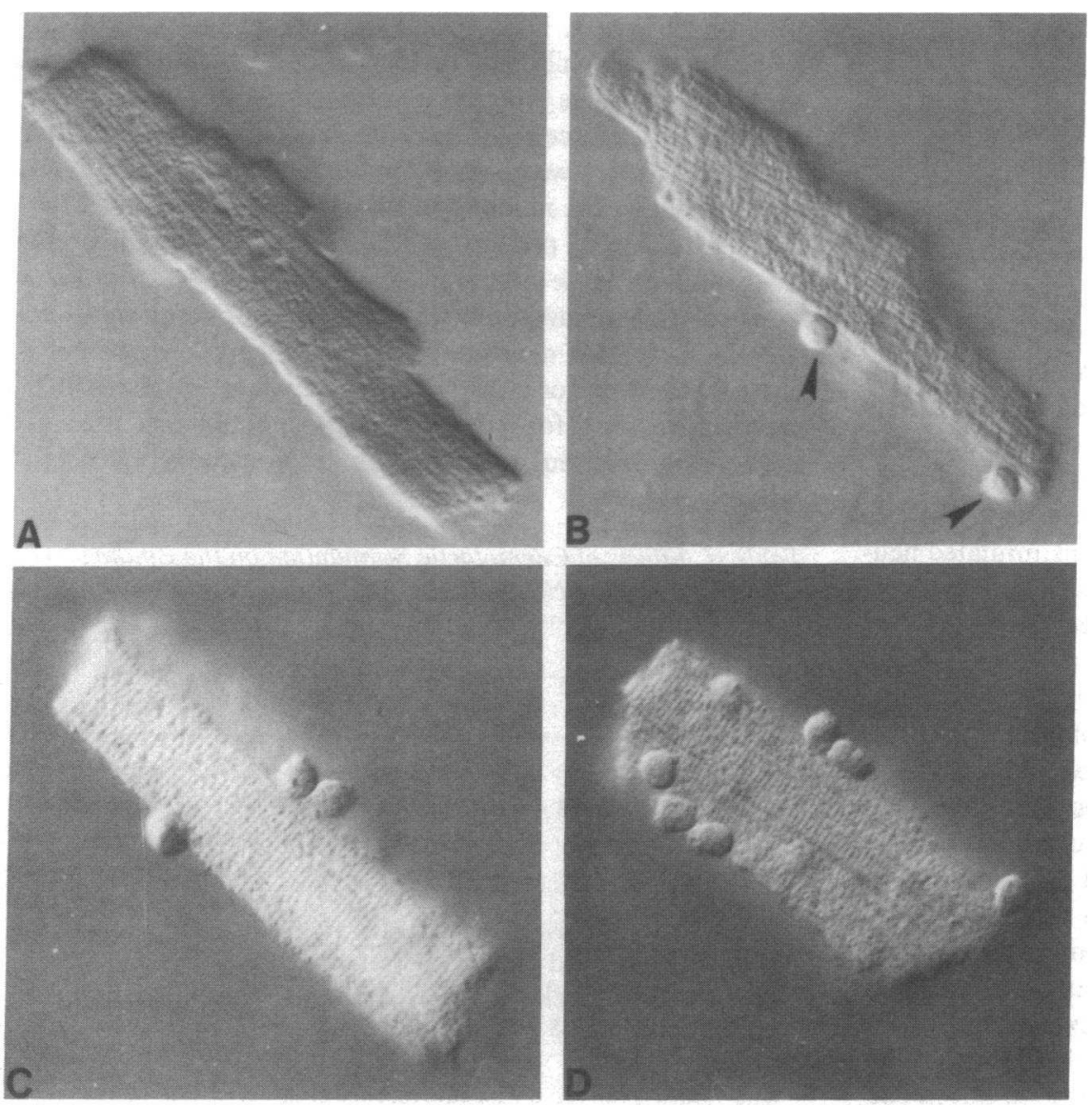

Figure 1. Differential interference contrast images of isolated canine myocytes and attached canine neutrophils. $A$, A myocyte from a control preparation without added stimulants or neutrophils. $B-D$, Myocytes from preparations after stimulation of the myocytes for $3 \mathrm{~h}$ with $4 \mathrm{U} / \mathrm{ml} \mathrm{IL-1}$, and neutrophils with ZAS (1\%). Note the contracted appearance of the myocyte in $D$ with numerous attached neutrophils. $\times 560$. 
Table I. Effects of Chemotactic Stimulation and MAb on the Adherence of Canine Neutrophils to Serum-treated Glass and Canine Endothelial Monolayers In Vitro

\begin{tabular}{lcccc}
\hline & \multicolumn{4}{c}{ \% Adherence } \\
\cline { 2 - 5 } Pretreatment of neutrophils* & $n$ & Serum, glass & $n$ & Endothelium \\
\hline S, 0.5\% & 4 & $25 \pm 3$ & 8 & $33 \pm 5$ \\
ZAS, 0.1\% & 4 & $33 \pm 2^{\ddagger}$ & & $\mathrm{ND}^{\S}$ \\
ZAS, 0.2\% & 4 & $49 \pm 3^{\ddagger}$ & 6 & $65 \pm 5^{*}$ \\
ZAS, 0.5\% & 4 & $50 \pm 3^{\ddagger}$ & & $\mathrm{ND}^{\S}$ \\
ZAS, 0.2\%, R15.7 & 4 & $18 \pm 2^{\prime \prime}$ & 6 & $33 \pm 6^{\prime \prime}$ \\
ZAS, 0.2\%, LM2/1 & 4 & $50 \pm 3$ & 4 & $61 \pm 4$ \\
ZAS, 0.2\%, IgG1 & 4 & $49 \pm 1$ & 3 & $70 \pm 4$ \\
$1 \%$ HSA & 5 & $16 \pm 1$ & 4 & $42 \pm 5$ \\
PAF, 10 ng/ml & 3 & $96 \pm 2^{\ddagger}$ & 4 & $89 \pm 4^{\ddagger}$ \\
PAF, 30 ng/ml & 4 & $97 \pm 1^{\ddagger}$ & 4 & $99 \pm 1^{\ddagger}$ \\
PAF, 200 ng/ml & 3 & $96 \pm 1^{\ddagger}$ & 3 & $98 \pm 1^{\ddagger}$ \\
PAF, 30 ng/ml, R15.7 & 4 & $28 \pm 8^{\prime}$ & 4 & $42 \pm 5^{\prime}$ \\
PAF, 200 ng/ml, R15.7 & 3 & $32 \pm 5^{\ddagger}$ & 3 & $44 \pm 9^{\ddagger}$ \\
PAF, 30 ng/ml, LM2/1 & 4 & $82 \pm 8$ & 4 & $86 \pm 5$ \\
PAF, 30 ng/ml, IgG1 & 4 & $89 \pm 7$ & 3 & $95 \pm 2$ \\
& & & & \\
\hline
\end{tabular}

* Canine neutrophils were preincubated for $5 \mathrm{~min}$ in canine serum $(S)$ or ZAS with and without the MAbs indicated $(5 \mu \mathrm{g} / \mathrm{ml})$, and HSA or PAF with and without the MAbs indicated. The solution containing the stimulants and MAbs was injected into the adhesion chamber and adherence determined using a visual assay. Serumtreated glass was prepared by exposing the glass coverslip to 3\% canine serum in PBS for 2 min and then washing in PBS. The endothelial cells were exposed to $2 \mathrm{ng} / \mathrm{ml} \mathrm{LPS}$ for $3 \mathrm{~h}$ before being washed and placed in the adhesion chamber. Adhesion of unstimulated neutrophils to unstimulated endothelial monolayers was $9 \pm 2 \%$.

${ }^{\ddagger} P<0.01$ compared with control.

The effects of this condition were not determined.

" $P<0.01$ compared with $0.2 \%$ ZAS stimulation without MAb.

' $P<0.01$ compared with $30 \mathrm{ng} / \mathrm{ml}$ PAF stimulation without MAb.

HSA, $32 \pm 3 \mu \mathrm{m} ; 200 \mathrm{ng} / \mathrm{ml}$ PAF, $101 \pm 8 \mu \mathrm{m}$ ), and increased the binding of MAbs R15.7 and LM2/1 to the neutrophil surface (Table II). These stimuli failed to increase neutrophil adherence to myocytes over a 1-h observation period (Fig. 3). However, exposure of the myocytes to IL- $1 \beta$ at concentrations as low as $0.5 \mathrm{U} / \mathrm{ml}$ for $3 \mathrm{~h}$ at $37^{\circ} \mathrm{C}$ resulted in marked increases in the adhesion of chemotactically stimulated neutrophils (Figs. 1, $B-D$ and 3). Stimulation of both the neutrophil and the myocyte appeared to be necessary since unstimulated neutrophils failed to adhere to IL- $1 \beta$-treated myocytes. The image in Fig. $1 D$ was typical of myocytes with multiple attached neutrophils. Such cells were often distinctly contracted in appearance, and in preparations observed after $1 \mathrm{~h}$ co-incubation, many myocytes with attached neutrophils exhibited the rounded configuration of those cells permeable to trypan blue. The IL- $1 \beta$-induced increase in adhesion appeared to require protein synthesis since addition of inhibitors of protein synthesis markedly reduced adhesion (Fig. 4), and enhanced adherence of neutrophils was not observed when IL- $1 \beta$ was added coincident with the neutrophils and the chemotactic stimulus and incubated for $30 \mathrm{~min}$ at $37^{\circ} \mathrm{C}$. Increases in adherence were observed after $1 \mathrm{~h}$ preincubation of the myocytes with IL-1 $\beta$ (4 $\mathrm{U} / \mathrm{ml}$ ) and reached the peak activity seen in Fig. 3 within $4 \mathrm{~h}$.

Another cytokine (TNF $\alpha$ ) promoted adhesion, but in con-

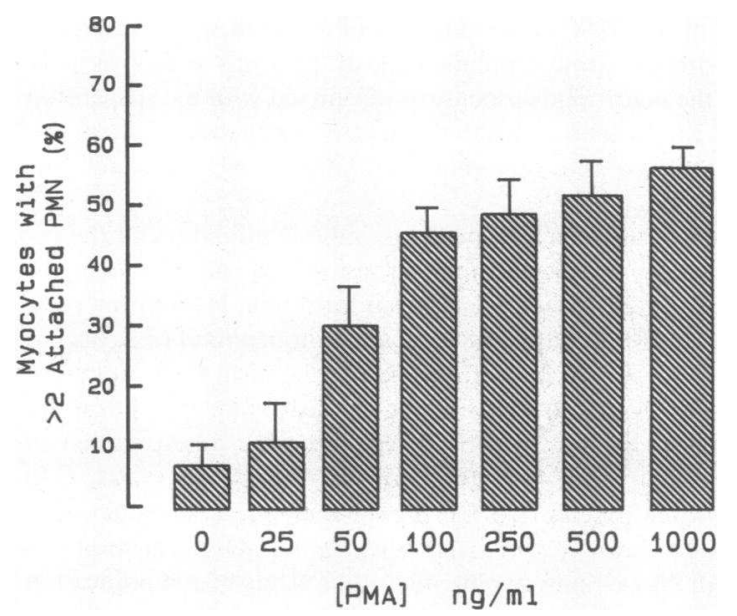

Figure 2. Effect of PMA on adhesion of canine neutrophils to canine myocytes. Neutrophils and myocytes were suspended together in the indicated concentration of PMA at $37^{\circ} \mathrm{C}$ for $1 \mathrm{~h}$. Adhesion was determined visually and expressed as the percentage of myocytes with more than two attached neutrophils. $n=6 ; P<0.01$ for each level of PMA stimulation compared with control.

trast to IL-1 $\beta$, appeared to be capable of stimulating both cell types since the addition of unstimulated neutrophils to myocyte suspensions containing TNF $\alpha$ resulted in marked increases in adhesion (Fig. 5). Adhesion was evident as early as 1 $h$ after exposure of the myocytes to TNF $\alpha$, but maximum stimulation was not seen until incubation of the myocytes with TNF $\alpha$ for $3 \mathrm{~h}$ before addition of the neutrophils.

Hydrogen peroxide production associated with neutrophilmyocyte adherence. $\mathrm{H}_{2} \mathrm{O}_{2}$ production was evident after incubation of neutrophils and PAF with IL-1 $\beta$-stimulated myocytes (Table III). As reported by Nathan (24) for human neutrophils on extracellular matrix proteins or endothelial monolayers, there was a considerable lag period before $\mathrm{H}_{2} \mathrm{O}_{2}$ was detected by the reduction in scopoletin fluorescence. Several controls were performed to assess the requirement for neutrophil-myocyte adhesion. Incubation of neutrophils in type I collagen-coated wells with PAF failed to result in detectable $\mathrm{H}_{2} \mathrm{O}_{2}$. Canine neutrophils did not adhere to type I collagen-coated plastic or glass surfaces even after prolonged incubations (e.g., $37^{\circ} \mathrm{C}$ for $2 \mathrm{~h}, n=4$ ). Exposure of the neutrophils to PAF and unstimulated myocytes did not lead to $\mathrm{H}_{2} \mathrm{O}_{2}$ pro-

Table II. Effects of Chemotactic Stimulation on the Binding of MAbs to Canine Neutrophils

\begin{tabular}{lcccccc}
\hline & \multicolumn{3}{c}{ Normal } & & \multicolumn{2}{c}{ CD18 deficient } \\
\cline { 2 - 4 } Antibody* & PBS & ZAS & PAF & & PBS & ZAS \\
\hline IgG1 & $4 \pm 1^{\ddagger}$ & $5 \pm 2$ & $5 \pm 2$ & & 4 & 3 \\
R15.7 & $85 \pm 13$ & $161 \pm 22$ & $172 \pm 19$ & & 5 & 3 \\
LM2/1 & $53 \pm 9$ & $116 \pm 12$ & $121 \pm 9$ & & 4 & 4
\end{tabular}

* Neutrophils from five normal dogs or from a dog with CD18 deficiency were evaluated using flow cytometry. Before labeling with the MAbs and FITC-labeled goat anti-mouse IgG antibody, neutrophils were incubated for $15 \mathrm{~min}$ at $37^{\circ} \mathrm{C}$ in either PBS, $1 \% \mathrm{ZAS}$, or 200 $\mathrm{ng} / \mathrm{ml}$ PAF.

$\ddagger$ The values given are mean fluorescence channel $( \pm \mathrm{SD})$ on a log scale. 


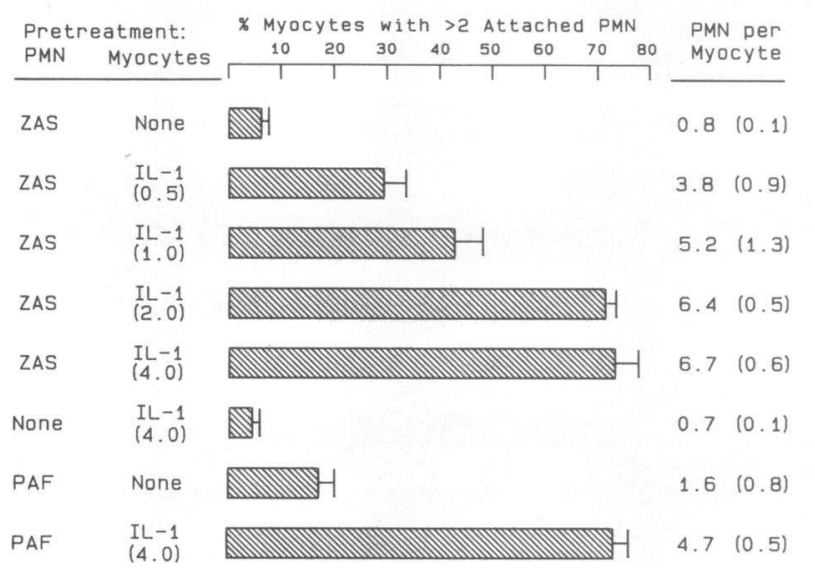

Figure 3. Effect of ZAS, PAF, and IL- $1 \beta$ on the adhesion of canine neutrophils to canine myocytes. Myocytes were incubated at $37^{\circ} \mathrm{C}$ with and without IL-1 $\beta(\mathrm{U} / \mathrm{ml})$ at the indicated concentration before the addition of neutrophils. Both cell types were then suspended together and incubated an additional $30 \mathrm{~min}$ at $37^{\circ} \mathrm{C}$. Neutrophils were stimulated with ZAS (1\%) or PAF $(200 \mathrm{ng} / \mathrm{ml}) 5 \mathrm{~min}$ before and during incubation with myocytes. Adhesion was determined visually. PMN per myocyte is expressed as mean (SD), $n=6$; all values for experiments with both ZAS and IL- $1 \beta$ stimulation are significant, $P<0.01$, compared with either ZAS alone or IL- $1 \beta$ alone. The values for experiments with both PAF and IL- $1 \beta$ are significant, $P<0.01$, when compared with either PAF or IL- $1 \beta$ stimulation alone.

duction, and the combination of unstimulated neutrophils with IL- $1 \beta$-stimulated myocytes was also ineffectual. Finally, IL- $1 \beta$-stimulated myocytes incubated alone with PAF (200 $\mathrm{ng} / \mathrm{ml}$ ) did not produce detectable $\mathrm{H}_{2} \mathrm{O}_{2}$.

CD18 dependence of neutrophil-myocyte adhesion and $\mathrm{H}_{2} \mathrm{O}_{2}$ production. MAb R 15.7 binds to CD18 on canine cells as indicated by the following experimental results: $(a)$ The clone producing this MAb was initially selected because of its ability to inhibit aggregation of both JY cells and SKW-3 cells, activities consistent with other anti-CD18 MAbs. (b) R15.7 bound to mouse-human hybridoma cells expressing hybrid heterodimers of mouse $\alpha$ and human $\beta$, but not cells expressing human $\alpha$ and mouse $\beta$. This indicates that this MAb recognizes human CD18. (c) It failed to bind to neutrophils from humans with CD18 deficiency (not shown) or a dog with

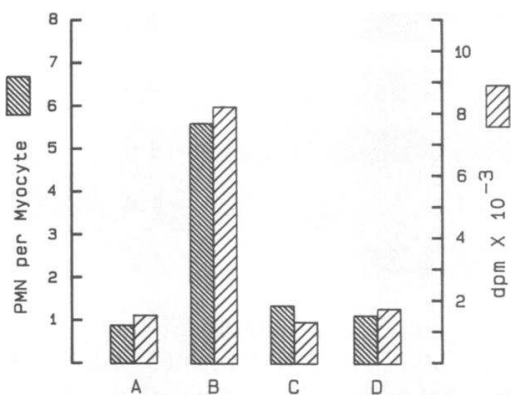

Figure 4. Adhesion of canine neutrophils to canine myocytes: effects of protein synthesis inhibitors. Myocytes were incubated for $3 \mathrm{~h}$ at $37^{\circ} \mathrm{C}$ without or with IL-1 $\beta(2 \mathrm{U} / \mathrm{ml})$ and inhibitors $(5 \mu \mathrm{g} / \mathrm{ml})$. Adhesion was determined visually using ZASstimulated canine neutrophils, and protein synthesis was assessed by the incorporation of $\left[{ }^{3} \mathrm{H}\right]$ leucine added at the beginning of the incubation with IL- $1 \beta . A$, Control conditions without IL-1 $\beta$. B, Control levels after stimulation with IL-1 $\beta . C, \mathrm{IL}-1 \beta$ stimulation in the presence of cycloheximide. $D$, IL-1 $\beta$ stimulation in the presence of actinomycin D. Results represent the mean values from two separate experiments for both adhesion and $\left[{ }^{3} \mathrm{H}\right]$ leucine incorporation.

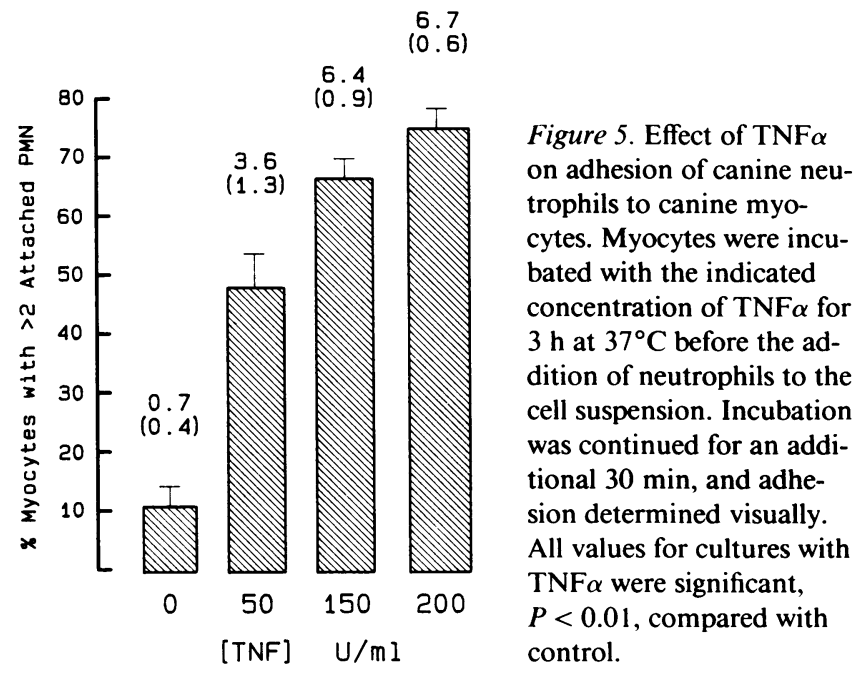

CD18 deficiency (Table II). (d) It markedly inhibited homotypic aggregation of human and canine (Fig. 6) neutrophils, a function consistent with the activity of anti-CD18 MAbs on human cells. (e) It immunoprecipitated both $\alpha$ and $\beta$ subunits consistent with leukocyte integrins from lysates of canine neutrophils (Fig. 7) (49).

The adhesion of canine neutrophils to canine myocytes induced by PMA, TNF $\alpha$, or the combination of chemotactic factor and IL- $1 \beta$ was markedly inhibited by MAb R 15.7 (Figs. 8 and 9). Furthermore, the adhesion of canine neutrophils to serum-coated glass and LPS-stimulated canine endothelial

Table III. $\mathrm{H}_{2} \mathrm{O}_{2}$ Production after Incubation of Canine Neutrophils and Cardiac Myocytes In Vitro

\begin{tabular}{lccccc}
\hline & \multicolumn{5}{c}{ Experiment number } \\
\cline { 2 - 6 } Experimental conditions & 1 & 2 & 3 & 4 & 5 \\
\hline $\begin{array}{c}\text { Stimulated myocytes } \\
\quad+\text { PMN + PAF* }\end{array}$ & $750^{\ddagger}$ & 404 & 742 & 700 & 734 \\
$\begin{array}{l}\text { Stimulated myocytes } \\
\quad+\text { PMN }\end{array}$ & $5.3^{\S}$ & $<5$ & $<5$ & 11.9 & 67.4 \\
$\begin{array}{l}\text { Stimulated myocytes } \\
+ \text { PAF }\end{array}$ & $<5$ & ND & $<5$ & $<5$ & $<5$ \\
$\begin{array}{l}\text { Unstimulated myocytes } \\
+ \text { PMN + PAF }\end{array}$ & ND" & 75.7 & $<5$ & $<5$ & $<5$ \\
$\begin{array}{l}\text { Unstimulated myocytes } \\
+ \text { PMN }\end{array}$ & ND & $<5$ & $<5$ & $<5$ & $<5$ \\
\hline
\end{tabular}

* Myocytes were stimulated for $3 \mathrm{~h}$ with IL- $1 \beta, 4 \mathrm{U} / \mathrm{ml}$, and then mixed with neutrophils and PAF $(200 \mathrm{ng} / \mathrm{ml})$ in type I collagencoated microtiter plate wells. The reduction in scopoletin fluorescence was used to determine the production of $\mathrm{H}_{2} \mathrm{O}_{2}$.

${ }^{\ddagger}$ Expressed as picomoles/well of $\mathrm{H}_{2} \mathrm{O}_{2}$ produced over a 100 -min observation period beginning after the initial lag phase. The lag phase in minutes for each of these experiments was $75,150,120,30$, and 25 , respectively.

${ }^{\S}$ Expressed as percent of the $\mathrm{H}_{2} \mathrm{O}_{2}$ produced by stimulated myocytes $+\mathrm{PMN}+\mathrm{PAF}$, determined using area under the curve of values plotted at 15-min intervals. Values given as $<5$ reflect $\mathrm{H}_{2} \mathrm{O}_{2}$ production too low to accurately measure.

"The effects of this condition were not determined. 


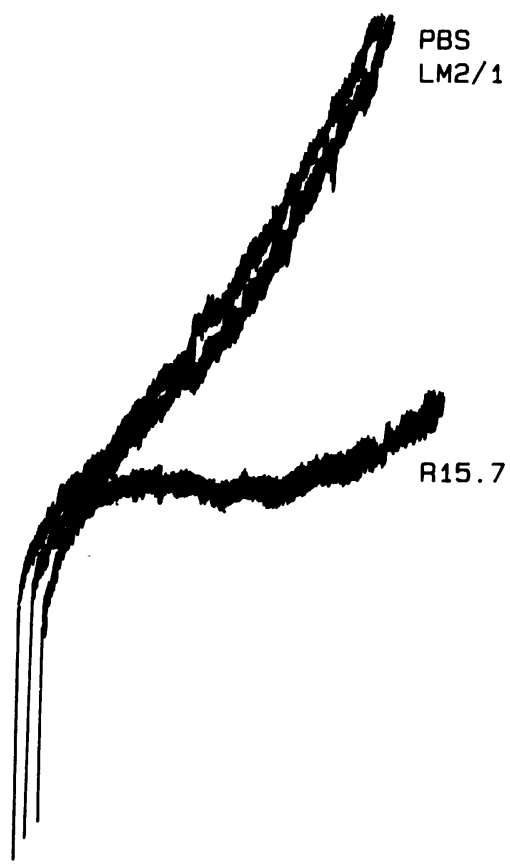

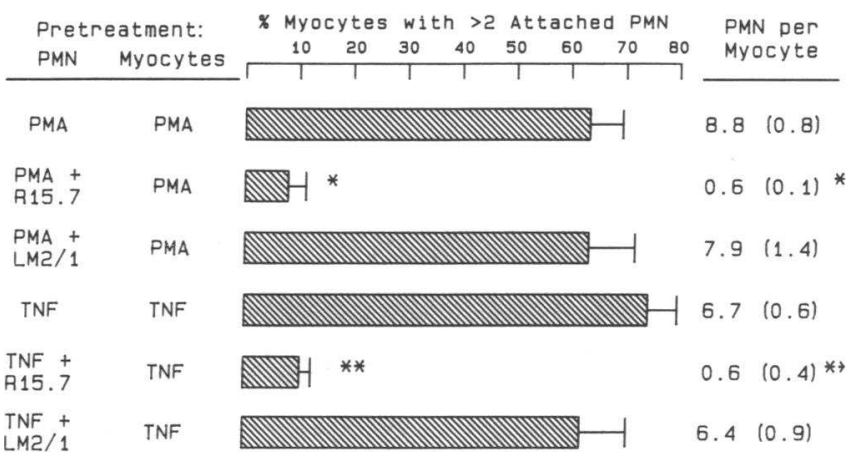

6. Homotypic aggregation of canine neutrophils: effects of MAbs R15.7 and LM2/1. Isolated canine neutrophils were suspended in PBS and stimulated with PMA $(200 \mathrm{ng} / \mathrm{ml})$, and aggregation was followed for 5 min. Representative tracings show inhibitory activity of R15.7. monolayers was increased by ZAS and PAF. This increase was blocked by MAb R15.7 (IgG1) but not by LM2/1 or IgG1 (Table I). Adhesion of neutrophils to unstimulated endothelial monolayers was increased by ZAS (control with no stimulation, $9 \pm 2 \%$ adherence; with $0.5 \%$ ZAS for $10 \mathrm{~min}, 18 \pm 4 \%$ adherence, $P<0.05, n=4)$. This increase was blocked by antibody R 15.7 (with $0.5 \%$ ZAS for $10 \mathrm{~min}$ in the presence of 5 $\mu \mathrm{g} / \mathrm{ml} \mathrm{R} 15.7,7 \pm 4 \%$ adherence, $P<0.05, n=3$ ) but not LM2/1 $(17 \pm 2 \%$ adherence, $n=3)$.

A second MAb, LM2/1 (IgG1), served as a control. This antibody, previously shown to recognize CD11b on human cells, binds to the surface of canine neutrophils but fails to

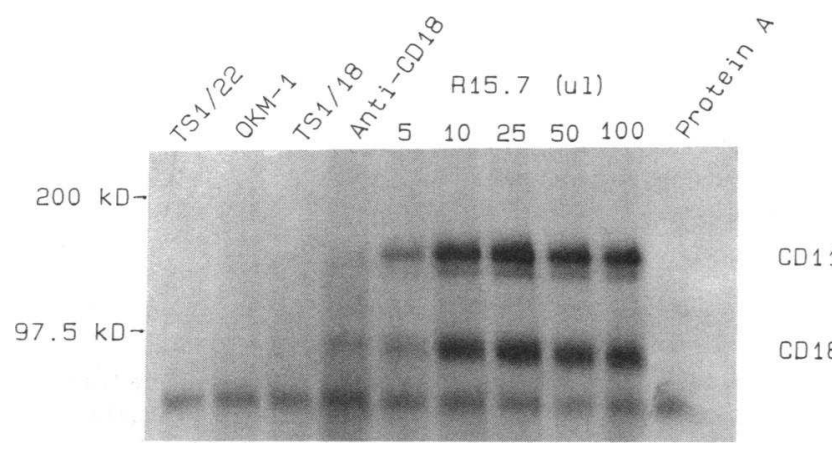

Figure 7. Immunoprecipitation of canine neutrophil lysates with antibodies TS1/22 (anti-human CD11a), OKM1 (anti-human CD11b), TS1/18 (anti-human CD18), anti-CD18 (rabbit polyclonal anti-human CD18), and R15.7 (anti-CD18). TS1/22 and OKM1 fail to bind to canine neutrophils or to immunoprecipitate antigen from canine cells. TS1/18 and the polyclonal anti-CD18 react weakly with canine cells. R15.7 reacts strongly with canine and human cells and immunoprecipitates at least two $\alpha$-chains (indicated as CD11 on this figure), a $\beta$-chain from canine neutrophils, and three $\alpha$-chains and a $\beta$-chain from human neutrophils (not shown). block adhesive functions that in human cells are mediated by Mac-1 (CD1 1b/CD18). For example, LM2/1 failed to inhibit homotypic aggregation of canine neutrophils (Fig. 6) and adhesion of canine neutrophils to serum-coated glass (Table I). This MAb failed to inhibit adhesion of canine neutrophils to canine myocytes (Figs. 8 and 9) and LPS-stimulated canine endothelial monolayers. A nonbinding control IgG1 also failed to inhibit adhesion in these settings (Table $I$ and Fig. 9).

As shown in Table IV, $\mathrm{H}_{2} \mathrm{O}_{2}$ production stimulated by IL- $1 \beta$ and PAF was reduced to low levels by addition of $\mathrm{R} 15.7$ $(5 \mu \mathrm{g} / \mathrm{ml})$. Control antibodies, IgG1 $(5 \mu \mathrm{g} / \mathrm{ml})$, and LM2/1 (5 $\mu \mathrm{g} / \mathrm{ml}$ ) did not inhibit $\mathrm{H}_{2} \mathrm{O}_{2}$ production.

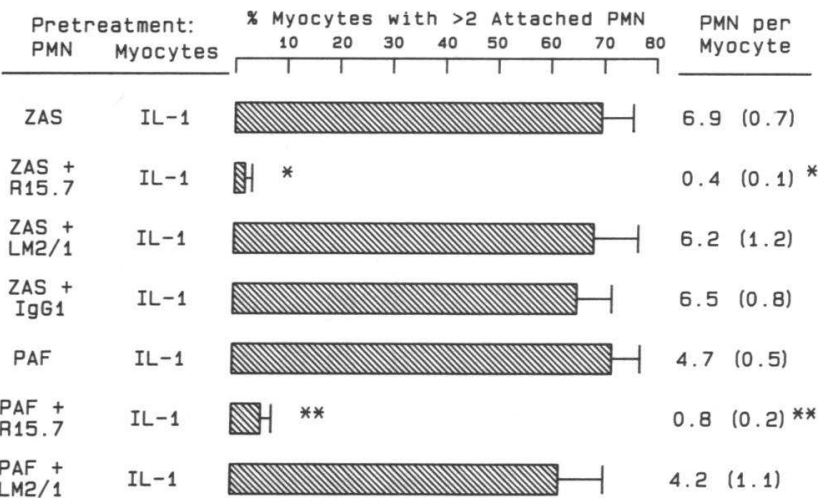

Figure 9. Effects of monoclonal antibodies on the adhesion of canine neutrophils to canine myocytes. Myocytes were incubated with IL-1 $\beta$ $(4 \mathrm{U} / \mathrm{ml})$ for $3 \mathrm{~h}$ at $37^{\circ} \mathrm{C}$. Neutrophils were incubated with the stimuli ( $1 \%$ ZAS or $200 \mathrm{ng} / \mathrm{ml} \mathrm{PAF)} \mathrm{and} \mathrm{MAbs} \mathrm{indicated} \mathrm{(R15.7,} \mathrm{anti-}$ CD18; LM2/1, anti-CD1 la; IgG1 nonbinding control) for $5 \mathrm{~min}$ before addition to the myocyte suspension. The stimuli and MAbs were retained with the cell suspensions, incubation was continued at $37^{\circ} \mathrm{C}$ for an additional $30 \mathrm{~min}$, and adhesion was determined visually. ${ }^{*} P$ $<0.001$ compared with control without MAb; ${ }^{* *} P<0.001$, compared with control without MAb. 
Table IV. Effects of MAb R15.7 on $\mathrm{H}_{2} \mathrm{O}_{2}$ Production by Canine Neutrophils Incubated with Canine Myocytes

\begin{tabular}{|c|c|c|c|c|c|c|}
\hline \multirow{2}{*}{$\begin{array}{l}\text { Experimental } \\
\text { conditions }\end{array}$} & \multicolumn{5}{|c|}{ Experiment number } & \multirow[b]{2}{*}{ Mean \pm SD } \\
\hline & 1 & 2 & 3 & 4 & 5 & \\
\hline $\mathrm{R} 15.7,5 \mu \mathrm{g} / \mathrm{ml}^{*}$ & $7.2^{\ddagger}$ & 15.8 & 7.5 & 10.9 & 4.6 & $9.2 \pm 4.3$ \\
\hline $\mathrm{LM} 2 / 1,5 \mu \mathrm{g} / \mathrm{ml}$ & $\mathrm{ND}^{\S}$ & 97.5 & 118.1 & 99.9 & ND & $105.2 \pm 11.3$ \\
\hline $\mathrm{IgG} 1,5 \mu \mathrm{g} / \mathrm{ml}$ & ND & 132.0 & 99.7 & 99.1 & 100.2 & $107.7 \pm 16.2$ \\
\hline
\end{tabular}

* Myocytes were stimulated for $3 \mathrm{~h}$ with IL- $1 \beta, 4 \mathrm{U} / \mathrm{ml}$, and then mixed with neutrophils, MAb as indicated, and PAF $(200 \mathrm{ng} / \mathrm{ml})$ in type I collagen-coated microtiter plate wells. The reduction is scopoletin fluorescence was used to determine the production of $\mathrm{H}_{2} \mathrm{O}_{2}$.

${ }^{\ddagger}$ Expressed as percent of the $\mathrm{H}_{2} \mathrm{O}_{2}$ produced by stimulated myocytes + PMN + PAF, determined using area under the curve of values plotted at 15 -min intervals.

$\S$ The effects of this condition were not determined.

\section{Discussion}

Adhesion of human neutrophils to human endothelial cells clearly involves $\operatorname{CD} 18(33,35,36,41-43,60,61)$. Chemotactic stimulation of the neutrophils significantly increases adherence, and this increase is largely CD18 dependent, since antiCD18 MAbs such as TS1/18 and 60.3 produce $>90 \%$ inhibition, and adherence of neutrophils from patients with CD18 deficiency is not increased by chemotactic stimulation. Stimulation of the endothelial cells with LPS, IL- $1 \beta$, or TNF $\alpha$ markedly increases adhesion of unstimulated neutrophils. This increase is partially dependent on ligand(s) for CD18 heterodimers as shown by the finding that the anti-CD18 antibodies produce $\sim 50 \%$ inhibition, and adhesion of CD18-deficient cells reaches only approximately half that of normal neutrophils adhering to cytokine-stimulated endothelial cells.

Canine neutrophils apparently utilize CD18 in their adherence to canine endothelial cells as shown by the results in this report. A MAb (R15.7) shown to recognize canine CD18 markedly inhibited the augmented adhesion induced by chemotactic stimulation. In addition, canine neutrophils also appear to utilize CD18 in adherence to cardiac myocytes. Stimulation of both cell types appears to be necessary and accounts for the results obtained with PMA and TNF $\alpha$. Studies of human cells have shown that these agents activate both neutrophils and endothelial cells to promote intercellular adherence $(35,41)$. IL-1 $\beta$, PAF, and ZAS used alone are apparently unable to stimulate both canine neutrophils and myocytes, since combinations of IL- $1 \beta$ and chemotactic stimulation were required for adherence. These results are also consistent with the response of human neutrophils and endothelial cells (42). Thus the canine neutrophil integrin involved appears to require activation since adhesion of unstimulated neutrophils to cytokine-stimulated myocytes was not increased over that of unstimulated neutrophils to unstimulated myocytes. The current experiments do not distinguish between a requirement for mobilization of CD18 from internal pools $(55,62-64)$ (a phenomenon that may explain the increased binding of MAbs R15.7 and LM2/1 seen in Table II), and the activation or clustering of existing surface integrin molecules, phenomena reported to occur on human neutrophils (65-69) but as yet unknown on canine cells.

The putative ligand on the myocyte involved in the attachment of neutrophils does not seem to be constitutively ex- pressed since stimulation (e.g., with IL-1 $\beta$ ) and protein synthesis are required for increased adhesion. While the identity of this ligand is unknown at present, two prominent human endothelial ligands for neutrophil adhesion, intercellular adhesion molecule-1 (ICAM-1) $(39,42,43,52)$ and endothelial leukocyte adhesion molecule-1 (ELAM-1) $(39,44)$, may have canine homologues. The CD18 dependence of the canine neutrophil-myocyte adhesion appears to exclude a role for an ELAM-1-like ligand, since adhesion of neutrophils to ELAM-1 does not appear to require CD18 heterodimers (70). ICAM-1 is a candidate since adhesion of neutrophils to this ligand is CD18 dependent $(42,43)$, and ICAM-1 is expressed on diverse cell types after cytokine stimulation (71). However, since CD18 heterodimers have been shown to form adhesive interactions with several different molecules $(27,72,73)$, the adhesive ligand on stimulated myocytes may be distinct from those on endothelial cells.

The co-incubation of PAF-stimulated neutrophils with IL- $1 \beta$-stimulated myocytes is accompanied by substantial production of $\mathrm{H}_{2} \mathrm{O}_{2}$. This phenomenon appears to be consistent with the adherence-dependent $\mathrm{H}_{2} \mathrm{O}_{2}$ production obtained with human neutrophils contacting extracellular matrix proteins or human endothelial cells $(24,25)$. The oxidative burst in our experiments with canine cells requires neutrophil-myocyte adhesion. This conclusion is supported by the finding that $\mathrm{H}_{2} \mathrm{O}_{2}$ production did not occur in the absence of adhesion: $(a)$ Neutrophils stimulated with PAF on type I collagen-coated plastic, a nonadhesive surface, did not produce $\mathrm{H}_{2} \mathrm{O}_{2}$. (b) Myocytes stimulated with IL- $1 \beta$ and PAF in the absence of neutrophils did not produce $\mathrm{H}_{2} \mathrm{O}_{2}$. (c) Neither unstimulated neutrophils on IL- $1 \beta$-stimulated myocytes nor stimulated neutrophils on unstimulated myocytes produced $\mathrm{H}_{2} \mathrm{O}_{2}$. (d) $\mathrm{H}_{2} \mathrm{O}_{2}$ production was inhibited in the presence of a MAb ( $\mathrm{R} 15.7)$ that blocked adhesion, but was not altered by the presence of antibodies (IgG1 and LM2/1) that did not alter adhesion. Thus it appears that chemotactically stimulated $\mathrm{H}_{2} \mathrm{O}_{2}$ production by canine cells, like that by human cells, is markedly potentiated by adhesion, and the CD18-dependent adhesion of neutrophils to myocytes can participate in this potentiation.

The occurrence and possible roles of neutrophil-myocyte adhesion and $\mathrm{H}_{2} \mathrm{O}_{2}$ generation in inflammatory injury (e.g., ischemia/reperfusion) to myocardial tissue remain to be defined. The plausibility of some contribution to tissue injury is supported by numerous studies in animal models of cardiac ischemia/reperfusion, and recent experiments in vitro. Antioxidants (e.g., superoxide dismutase and catalase) clearly reduce the area of tissue damage (74-76), though the specific sites of action have not been defined. Also, antiadhesive therapy, the use of the MAb 904 (anti-CD11b/CD18) (15, 77), reduced the area of tissue damage in a canine model, though the specific adhesive events blocked by this antibody in vivo have not been defined. Lymph draining ischemic and reperfused canine cardiac tissue has been found capable of activating canine neutrophil adhesion to canine endothelial cells in vitro (78), and in recent studies (unpublished data) we found that dilutions of postischemic canine cardiac lymph can, over a 3-h period, induce myocytes to become adhesive for ZASstimulated neutrophils. In addition, isolated cardiac myocytes are clearly susceptible to damage by $\mathrm{H}_{2} \mathrm{O}_{2}$ (79). Such observations support the possibility that the neutrophil-myocyte adhesion and $\mathrm{H}_{2} \mathrm{O}_{2}$ production observed in the present report may play significant roles in myocardial inflammation. 


\section{Acknowledgments}

The authors acknowledge the excellent technical assistance of B. J. Hughes, the secretarial assistance of Irene Harrison, and the helpful discussions with Dr. Donald C. Anderson and Dr. Roger Rossen and their critical review of the manuscript.

This study was supported in part by grants HL-23161, HL-42550, and HL-41408 from the National Institutes of Health, and grant 88G-205 from the American Heart Association, Texas Affiliate. Scott B. Shappell is supported in part by a Pharmaceutical Manufacturer's Association Foundation Medical Student Research Fellowship and by a SmithKline Beckman Medical Scientist Predoctoral Fellowship. William J. Dreyer's work was performed during the tenure of a Clinician Scientist Award from the American Heart Association and Boehringer Ingelheim Pharmaceuticals, Inc.

\section{References}

1. Mullane, K. M., W. Westlin, and R. Kraemer. 1988. Activated neutrophils release mediators that may contribute to myocardial injury and dysfunction associated with ischemia and reperfusion. $N Y$ Acad. Sci.

2. Mehta, J. L., W. W. Nichols, and P. Mehta. 1988. Neutrophils as potential participants in acute myocardial ischemia: Relevance to reperfusion. JACC (J. Am. Coll. Cardiol.). 11:1309-1316.

3. Mullane, K. M., N. Read, J. A. Salmon, and S. Moncada. 1984 Role of leukocytes in acute myocardial infarction in anesthetized dogs: relationship to myocardial salvage by anti-inflammatory drugs. $J$. Pharmacol. Exp. Ther. 228:510-522.

4. Smith, E. F., J. W. Egan, P. J. Bugelshi, L. M. Hillegass, D. E. Hill, and D. E. Griswold. 1988. Temporal relation between neutrophi accumulation and myocardial reperfusion injury. Am. J. Physiol. 255:H1060-H1068.

5. Mullane, K. M., R. Kraemer, and B. Smith. 1985. Myeloperoxidase activity as a quantitative assessment of neutrophil infiltration into ischemic myocardium. J. Pharmacol. Exp. Ther. 14:157-167.

6. Engler, R. L., M. D. Dahlgren, M. A. Peterson, A. Dobbs, and G. W. Schmid-Schonbein. 1986. Accumulation of polymorphonuclear leukocytes during $3 \mathrm{~h}$ experimental myocardial ischemia. Am. J. Physiol. 251:H93-H100.

7. Go, L. O., C. E. Murry, V. J. Richard, G. R. Weischedel, R. B Jennings, and K. A. Reimer. 1988. Myocardial neutrophil accumulation during reperfusion after reversible or irreversible ischemic injury. Am. J. Physiol. 255:H1188-H1198.

8. Mullane, K. M. 1987. Myocardial ischemia-reperfusion injury: role of neutrophils and neutrophil derived mediators. In Human Inflammatory Disease. G. Marone, L. M. Lichtenstein, M. Condorell, and A. S. Fauci, editors. Decker, Philadelphia. 143-159.

9. Romson, J. L., B. G. Hook, S. L. Kunkel, G. D. Abrams, M. A. Schork, and B. R. Lucchesi. 1983. Reduction of the extent of ischemic myocardial injury by neutrophil depletion in the dog. Circulation. 67:1016-1023.

10. Jolly, S. R., W. J. Kane, B. G. Hook, G. D. Abrams, S. L. Kunkel, and B. R. Lucchesi. 1986. Reduction of myocardial infarct size by neutrophil depletion: effect of duration of occlusion. Am. Heart J. 112:682-690.

11. deLorgeril, M., A. Basmadjian, M. Lavallee, R. Clement, D. Millette, G. Rousseau, and J. G. Latour. 1989. Influence of leukopenia on collateral flow, reperfusion flow, reflow ventricular fibrillation, and infarct size in dogs. Am. Heart J. 117:523-532.

12. Engler, R. L., M. D. Dahlgren, D. D. Morris, M. A. Peterson, and G. W. Schmid-Schonbein. 1986. Role of leukocytes in response to acute myocardial ischemia and reflow in dogs. Am. J. Physiol. 251:H314-H323.

13. Romson, J. L., B. G. Hook, V. H. Rigot, M. A. Schork, D. P. Swanson, and B. R. Lucchesi. 1982. The effect of ibuprofen on accumulation of ${ }^{111}$ Indium labeled platelets and leukocytes in experimental myocardial infarction. Circulation. 66:1002-1011.

14. Simpson, P. J., J. Mickelson, J. C. Fantone, K. P. Gallagher, and B. R. Lucchesi. 1987. Iloprost inhibits neutrophil function in vitro and in vivo and limits experimental infarct syze in canine heart. Circ. Res. 60:666-673.

15. Simpson, P. J., III, R. F. Todd, J. C. Fantone, J. K. Mickelson, J. D. Griffin, and B. R. Lucchesi. 1988. Reduction of experimental canine myocardial reperfusion injury by a monoclonal antibody (antiMo1, anti-CD11b) that inhibits leukocyte adhesion. J. Clin. Invest. $81: 624-629$.

16. Forman, M. B., S. Bingham, H. A. Kopelman, C. Wehr, M. P. Sandler, F. Koldgie, W. K. Vaughan, G. C. Friesinger, and R. Virmani. 1985. Reduction of infarct size with intracoronary perfluorochemical in a canine preparation of reperfusion. Circulation. 71:1060-1068.

17. Olafsson, B., M. B. Forman, D. W. Puett, A. Pou, C. V. Cates, G. C. Friesinger, and R. Virmani. 1987. Reduction of reperfusion injury in the canine preparation by intracoronary adenosine: importance of the endothelium and the no-reflow phenomenon. Circulation. 76:1135-1145.

18. Bednar, M., B. Smith, A. Pento, and K. M. Mullane. 1985. Nafazatrom-induced salvage of ischemic myocardium in anesthetized dogs is mediated through inhibition of neutrophil function. Circ. Res. 57:131-141.

19. Engler, R. L., G. W. Schmid-Schonbein, and R. S. Parelec. 1983. Leukocyte capillary plugging in myocardial ischemia and reperfusion in the dog. Am. J. Pathol. 111:98-111.

20. Schmid-Schonbein, G. W., and R. L. Engler. 1987. Granulocytes as active participants in acute myocardial ischemia and infarction. Am. J. Cardiovasc. Pathol. 1:15-30.

21. Anderson, D. C., F. C. Schmalstieg, W. T. Shearer, K. BeckerFreeman, S. Kohl, C. W. Smith, M. F. Tosi, and T. A. Springer. 1985. Leukocyte LFA-1, OKM1, p150,95 deficiency syndrome: functional and biosynthetic studies in three kindreds. Fed. Proc. 44:2671-2677.

22. Arfors, K. E., C. Lundberg, L. Lindbom, K. Lundberg, P. G. Beatty, and J. M. Harlan. 1987. A monoclonal antibody to the membrane glycoprotein complex CD18 inhibits polymorphonuclear leukocyte accumulation and plasma leakage in vivo. Blood. 69:338-340.

23. House, S. D., and H. H. Lipowsky. 1987. Leukocyte-endothelium adhesion: microhemodynamics in mesentery of the cat. Microvasc. Res. 34:363-379.

24. Nathan, C. F. 1987. Neutrophil activation on biological surfaces. Massive secretion of hydrogen peroxide in response to products of macrophages and lymphocytes. J. Clin. Invest. 80:1550-1560.

25. Nathan, C. F. 1989. Respiratory burst in adherent human neutrophils. Triggering by colony-stimulating factors CSF-GM and CSF-G. Blood. 73:301-306.

26. Wright, S. D., and B. C. Meyer. 1988. The fibronectin receptor of human macrophages recognizes the amino acid sequence, Arg-GlyAsp-Ser. J. Exp. Med. 162:762-766.

27. Wright, S. D., S. M. Levin, M. T. C. Jong, Z. Chad, and L. G. Kabbash. 1989. CR3 (CD11b/CD18) expresses one binding site for Arg-Gly-Asp-containing peptides and a second site for bacterial lipopolysaccharide. J. Exp. Med. 169:175-183.

28. Brown, A. F. 1982. Neutrophil granulocytes: adhesion and locomotion on collagen substrata in collagen matrices. $J$. Cell Sci. $58: 455-467$.

29. Brown, E. J., and J. L. Goodwin. 1988. Fibronectin receptors of phagocytes. Characterization of the Arg-Gly-Asp binding proteins of human monocytes and polymorphonuclear leukocytes. J. Exp. Med. 167:777-793.

30. Gresham, H. D., J. L. Goodwin, P. M. Allen, D. C. Anderson, and E. J. Brown. 1989. A novel member of the integrin receptor family mediates Arg-Gly-Asp (RGD)-stimulated neutrophil phagocytosis. $J$. Cell Biol. 108:1935-1944.

31. Gimbrone, M. A., Jr., A. F. Brock, and A. I. Schafer. 1984. Leukotriene $B_{4}$ stimulates polymorphonuclear leukocyte adhesion to cultured vascular endothelial cells. J. Clin. Invest. 74:1552-1555.

32. Tonnesen, M. G., L. A. Smedley, and P. M. Henson. 1984. Neutrophil-endothelial cell interactions. Modulation of neutrophil adhesiveness induced by complement fragments C5a and C5a des arg and 
formyl-methionyl-leucyl-phenylalanine in vitro. J. Clin. Invest. 74:1581-1592.

33. Tonnesen, M. G., D. C. Anderson, T. A. Springer, A. Knedler, N. Avdi, and P. M. Henson. 1989. Adherence of neutrophils to cultured human microvascular endothelial cells. Stimulation by chemotactic peptides and lipid mediators and dependence upon the Mac-1, LFA-1, p150,95 glycoprotein family. J. Clin. Invest. 83:637-646.

34. Charo, I. F., C. Yuen, H. D. Perez, and I. M. Goldstein. 1986. Chemotactic peptides modulate adherence of human polymorphonuclear leukocytes to monolayers of cultured endothelial cells. J. Immunol. 136:3412-3419.

35. Pohlman, T. H., K. A. Stanness, P. G. Beatty, H. D. Ochs, and J. M. Harlan. 1986. An endothelial cell surface factors(s) induced in vitro by lipopolysaccharide, interleukin-1, and tumor necrosis factor increases neutrophil adherence by a CDw 18 (LFA)-dependent mechanism. J. Immunol. 136:4548-4553.

36. Zimmerman, G. A., and T. M. McIntyre. 1988. Neutrophil adherence to human endothelium in vitro occurs by CDw18 (Mol, MAC-1/LFA-1/GP150,95) glycoprotein-dependent and independent mechanisms. J. Clin. Invest. 81:531-537.

37. Zimmerman, G. A., T. M. McIntyre, and S. M. Prescott. 1985. Thrombin stimulates the adherence of neutrophils to human endothelial cells in vitro. J. Clin. Invest. 76:2235-2246.

38. Dunn, C. J., and W. E. Fleming. 1984. Increased adhesion of polymorphonuclear leukocytes to vascular endothelium by specific interaction of endogenous (interleukin-1) and exogenous (lipopolysaccharide) substances with endothelial cells "in vitro." Eur. J. Rheumatol. Inflammation. 7:80-86.

39. Pober, J. S., M. A. Gimbrone, L. A. Lapierre, D. L. Mendrick, W. Fiers, R. Rothlein, and T. A. Springer. 1986. Activation of human endothelium by lymphokines: overlapping patterns of antigenic modulation by interleukin 1, tumor necrosis factor and immune interferon. J. Immunol. 137:1893-1896.

40. Pober, J. S., L. A. Lapierre, A. H. Stolpen, T. A. Brock, T. A. Springer, W. Fiers, M. P. Bevilacqua, D. L. Mendrick, and M. A. Gimbrone, Jr. 1987. Activation of cultured human endothelial cells by recombinant lymphotoxin: comparison with tumor necrosis factor and interleukin 1 species. J. Immunol. 138:3319-3324.

41. Gamble, J. R., J. M. Harlan, S. J. Klebanoff, and M. A. Vadas. 1985. Stimulation of the adherence of neutrophils to umbilical vein endothelium by human recombinant tumor necrosis factor. Proc. Natl. Acad. Sci. USA. 82:8667-8674.

42. Smith, C. W., R. Rothlein, B. J. Hughes, M. M. Mariscalco, F. C. Schmalstieg, H. E. Rudloff, and D. C. Anderson. 1988. Recognition of an endothelial determinant for CD18-dependent human neutrophil adherence and transendothelial migration. J. Clin. Invest. 82:1746-1756.

43. Smith, C. W., S. D. Marlin, R. Rothlein, C. Toman, and D. C. Anderson. 1989. Cooperative interactions of LFA-1 and Mac-1 with ICAM-1 in facilitating adherence and transendothelial migration of human neutrophils. J. Clin. Invest. 83:2008-2017.

44. Bevilacqua, M. P., J. S. Pober, D. L. Mendrick, R. S. Cotran, and M. A. Gimbrone, Jr. 1987. Identification of an inducible endothelial-leukocyte adhesion molecule. Proc. Natl. Acad. Sci. USA. 84:9238-9242.

45. Breviario, F., F. Bertocchi, E. Dejana, and F. Bussolino. 1988. IL-1-induced adhesion of polymorphonuclear leukocytes to cultured human endothelial cells: role of platelet-activating factor. J. Immunol. 141:3391-3397.

46. Furie, M. B., B. L. Naprstek, and S. C. Silverstein. 1987. Migration of neutrophils across monolayers of cultured microvascular endothelial cells. J. Cell Sci. 88:161-175.

47. Furie, M. B., and D. D. McHugh. 1987. Stimulation of neutrophil transendothelial migration by interleukin-1. J. Cell Biol. 105:276a. (Abstr.)

48. Beesley, J. E., J. D. Pearson, A. Hutchings, J. S. Carleton, and J. L. Gordon. 1979. Granulocyte migration through endothelium in culture. J. Cell Sci. 38:237-248.
49. Giger, U., L. A. Boxer, P. J. Simpson, B. R. Lucchesi, and R. F. Todd III. 1987. Deficiency of leukocyte surface glycoproteins Mol, LFA-1, and Leu M5 in a dog with recurrent bacterial infections. An animal model. Blood. 69:1622-1630.

50. Miller, L. J., D. F. Bainton, N. Borregaard, and T. A. Springer. 1987. Stimulated mobilization of monocyte Mac-1 and p150,95 adhesion proteins from an intracellular vesicular compartment to the cell surface. J. Clin. Invest. 80:185-191.

51. Galfre, G., S. C. Howe, C. Milstein, G. W. Butcher, and J. C. Howard. 1977. Antibodies to major histocompatibility antigens produced by hybrid cell lines. Nature (Lond.). 266:550.

52. Rothlein, R., M. L. Dustin, S. D. Marlin, and T. A. Springer. 1986. An intercellular adhesion molecule (ICAM-1) distinct from LFA-1. J. Immunol. 137:1270-1275.

53. Marlin, S. D., C. C. Morton, D. C. Anderson, and T. A. Springer. 1986. LFA-1 immunodeficiency disease. Definition of the genetic defect and chromosomal mapping of alpha and beta subunits by complementation in hybrid cells. J. Exp. Med. 164:855-867.

54. Anderson, D. C., K. L. B. Freeman, B. Heerdt, B. J. Hughes, R. M. Jack, and C. W. Smith. 1987. Abnormal stimulated adherence of neonatal granulocytes. Impaired induction of surface Mac-1 by chemotactic factors or secretagogues. Blood. 70:740-750.

55. Anderson, D. C., L. J. Miller, F. C. Schmalstieg, R. Rothlein, and T. A. Springer. 1986. Contributions of the Mac-1 glycoprotein family to adherence-dependent granulocyte functions: structure-function assessments employing subunit-specific monoclonal antibodies. $J$. Immunol. 137:15-27.

56. Smith, C. W., J. C. Hollers, R. A. Patrick, and C. Hassett. 1979. Motility and adhesiveness in human neutrophils. Effects of chemotactic factors. J. Clin. Invest. 63:221-229.

57. Ford, J. W., W. E. Burkel, and R. H. Kahn. 1981. Isolation of adult canine endothelium for tissue culture. In Vitro (Rockville). 17:44-52.

58. Sen, S., C. Petscher, and N. Ratliff. 1987. A factor that initiates myocardial hypertrophy in hypertension. Hypertension (Dallas). 9:261-267.

59. Farmer, B. B., M. Mancina, E. S. Williams, and A. M. Watanabe. 1988. Isolation of calcium tolerant myocytes from adult rat hearts: review of the literature and description of a method. Life Sci. 33:1-18.

60. Harlan, J. M. 1985. Leukocyte-endothelial cell interactions. Blood. 65:513-525.

61. Harlan, J. M., P. D. Killen, F. M. Senecal, B. R. Schwartz, E. K. Yee, R. F. Taylor, P. G. Beatty, T. H. Price, and H. D. Ochs. 1985. The role of neutrophil membrane glycoprotein GP-150 in neutrophil adherence to endothelium in vitro. Blood. 66:167-178.

62. O’Shea, J. J., E. J. Brown, B. E. Seligmann, J. A. Metcalf, M. M. Frank, and J. I. Gallin. 1985. Evidence for distinct intracellular pools of receptors for $\mathrm{C} 3 \mathrm{~b}$ and $\mathrm{C} 3 \mathrm{bi}$ in human neutrophils. J. Immunol. 134:2580-2587.

63. Petty, H. R., J. W. Francis III, R. F. Todd, P. R. Petrequin, and L. A. Boxer. 1987. Neutrophil C3bi receptors: Formation of membrane clusters during cell triggering requires intracellular granules. $J$. Cell. Physiol. 133:235-242.

64. Jones, D. H., F. C. Schmalstieg, B. L. Burr, H. E. Rudloff, C. W. Smith, S. S. Krater, and D. C. Anderson. 1988. A mobilizable Mac-1 (CR-3) pool co-localizes with gelatinase in neutrophils. FASEB (Fed. Am. Soc. Exp. Biol.) J. 2:A1583. (Abstr.)

65. Vedder, N. B., and J. M. Harlan. 1988. Increased surface expression of CD1 1b/CD18 (Mac-1) is not required for stimulated neutrophil adherence to cultured endothelium. J. Clin. Invest. 81:676682.

66. Philips, M., J. Buyon, R. Winchester, G. Weissmann, and S. Abramson. 1988. Upregulation of $\mathrm{iC} 3 \mathrm{~b}$ receptors (CR3) is neither necessary nor sufficient to promote neutrophil aggregation. J. Clin. Invest. 82:495-501.

67. Detmers, P. A., S. D. Wright, E. Olsen, B. Kimball, and Z. A. 
Cohn. 1987. Aggregation of complement receptors on human neutrophils in the absence of ligand. J. Cell Biol. 105:1137-1145.

68. Altieri, D. C., and T. S. Edgington. 1988. The saturable high affinity association of Factor X to ADP-stimulated monocytes defines a novel function of the Mac-1 receptor. J. Biol. Chem. 263:7007-7015.

69. Lo, S. K., P. A. Detmers, S. M. Levin, and S. D. Wright. 1989. Transient adhesion of neutrophils to endothelium. J. Exp. Med. 169:1779-1793.

70. Luscinskas, F. W., A. F. Brock, M. A. Arnaout, and M. A. Gimbrone, Jr. 1989. Endothelial-leukocyte adhesion molecule-1-dependent and leukocyte (CD11/CD18)-dependent mechanisms contribute to polymorphonuclear leukocyte adhesion to cytokine-activated human vascular endothelium. J. Immunol. 142:2257-2263.

71. Dustin, M. L., R. Rothlein, A. K. Bhan, C. A. Dinarello, and T. A. Springer. 1986. Induction by IL-1 and interferon-gamma: tissue distribution, biochemistry, and function of a natural adherence molecule (ICAM-1). J. Immunol. 137:245-254.

72. Wright, S. D., S. K. Lo, and P. A. Detmers. 1989. Specificity and regulation of CD18-dependent adhesions. In Structure and Function of Molecules Involved in Leukocyte Adhesion. T. A. Springer, D. C. Anderson, R. Rothlein, and A. S. Rosenthal, editors. SpringerVerlag New York Inc., New York. 190-207.

73. Staunton, D. E., M. L. Dustin, and T. A. Springer. 1989. Functional cloning of ICAM-2, a cell adhesion ligand for LFA-1 homologous to ICAM-1. Nature (Lond.). 339:61-64.

74. Rowe, G. T., N. H. Manson, M. Caplan, and M. L. Hess. 1983. Hydrogen peroxide and hydroxyl radical mediation of activated leu- kocyte depression of cardiac sarcoplasmic reticulum: participation of the cyclooxygenase pathway. Circ. Res. 53:584-591.

75. Werns, S., P. Simpson, K. Gallager, J. Michelson, M. Shea, B. Pitt, and B. Lucchesi. 1986. Effect of superoxide dismutase on leukocyte accumulation and infarct size after myocardial ischemia-reperfusion. Circulation. 74:347. (Abstr.)

76. Werns, S., P. Simpson, K. Gallager, J. Michelson, M. Shea, B. Pitt, and B. Lucchesi. 1988. Sustained limitation by superoxide dismutase of canine myocardial injury due to regional ischemia followed by reperfusion. J. Cardiovasc. Pharmacol. 11:36-44.

77. Todd, R. F., III, P. J. Simpson, and B. R. Lucchesi. 1989. The anti-inflammatory properties of monoclonal anti-Mol (CD1 lb/ $\mathrm{CD} 18$ ) antibodies in vitro and in vivo. In Structure and Function of Molecules Involved in Leukocyte Adhesion. T. A. Springer, D. C. Anderson, R. Rothlein, and A. S. Rosenthal, editors. Springer-Verlag New York Inc., New York. 125-137.

78. Dreyer, W. J., C. W. Smith, L. H. Michael, R. D. Rossen, B. J. Hughes, M. L. Entman, and D. C. Anderson. 1989. Demonstration of neutrophil chemotactic activity in canine cardiac lymph associated with myocardial injury during ischemia and reperfusion. Circ. Res. 65:1751-1762.

79. Kaminishi, T., and K. J. Kako. 1988. Mechanism of $\mathrm{H}_{2} \mathrm{O}_{2}$-induced acceleration of calcium influx into isolated rat heart myocytes. In Biology of Isolated Adult Cardiac Myocytes. W. A. Clark, R. S. Decker, and T. K. Borg, editors. Elsevier Science Publishing Co., Inc., New York. 220-223. 